\title{
"AND THE ANGEL WILL NOT COME": W. H. AUDEN AND THE PARADOX OF POETIC LANGUAGE
}

\section{“AND THE ANGEL WILL NOT COME": W. H. AUDEN Y LA PARADOJA DEL LENGUAJE POÉTICO}

\author{
Paula Baldwin Lind \\ Universidad de los Andes \\ pbaldwin@uandes.cl
}

\begin{abstract}
Resumen:
El objetivo de este artículo es analizar las nociones de poesía y de lenguaje poético que propone W. H. Auden (1907-1973) desde su perspectiva de crisis de la cultura moderna, en una selección de ensayos y poemas, con especial énfasis en "Autumn Song" (1936). En esta obra, el ángel que no llega a la Tierra, la parálisis de los seres vivos y el silencio dominante muestran las limitaciones del lenguaje humano al intentar dar cuenta de la realidad y de las experiencias personales. Aunque la figura del espíritu celeste, la estación de otoño en que se enmarca el poema y las imágenes de desencanto resultan claves para su interpretación, es fundamental considerar las ideas religiosas y filosóficas que Auden desarrolló durante su carrera, las que permiten comprender mejor su poética. Paradójicamente, a la vez que el poeta angloamericano reconoce la limitación de las palabras, encuentra en el lenguaje poético un camino posible para conocer y explorar lo que significa ser humano con todo su misterio.
\end{abstract}

Palabras clave: W. H. Auden, lenguaje poético, silencio, desencanto, conocimiento.

\begin{abstract}
:
The aim of this article is to analyze the notions of poetry and poetic language proposed by W. H. Auden (1907-1973) from his perspective of crisis of modern culture, in a selection of essays and poems, with special emphasis on "Autumn Song" (1936). In this work, the angel who does not arrive to the Earth, the paralysis of living creatures and the dominant silence show the limitations of human language when trying to account for reality and personal experiences. Although the figure of the celestial spirit, the autumn season in which the poem is framed and the images of disenchantment are key to its interpretation, it is essential to consider the religious and philosophical ideas that Auden developed during his career, which allow us to better understand his poetics. Paradoxically, at the same time that the Anglo-American poet acknowledges the limitation of words, he finds in poetic language a possible way to know and explore what it means to be human with all the mystery of it.
\end{abstract}

Keywords: W. H. Auden, poetic language, silence, disenchantment, knowledge.

Recibido: 10 de septiembre de 2020

Aceptado: 06 de noviembre de 2020 
Artículo. Paula Baldwin Lind. “'And the angel will not come': W. H. Auden and the Paradox of Poetic Language".

\section{Introduction: Auden's Poetical and Philosophical Background}

Wystan Hugh Auden (1907-1973), more commonly known as W. H. Auden, was one of the most influential voices in twentieth-century poetry. He assimilated the techniques of his modernist predecessors William Butler Yeats and T. S. Eliot, who had dominated English verse for years. With his formal and radically new style, the AngloAmerican poet became the leader of the British and Irish writers of the Thirties, together with the left-wing poets Stephen Spender, Cecil Day Lewis, and Louis MacNeice ${ }^{1}$, regardless that they never formed a consolidated group ${ }^{2}$. Critics like Samuel Hynes would come to identify these authors, as well as Christopher Isherwood and Edward Upward, among others, as “The Auden generation” (17,30). Born in York, England, Auden's life is viewed as being divided into two stages: English and American. His initial years established the framework for his deep-rooted commitment with science, psychoanalysis and Christianity. As the 1930s moved closer towards war, Auden became one of the main representatives of his age, a political essayist warning against the risks of totalitarian regimes.

Auden's publications range from poems to songs, dramatic writings, prose works, lectures, and libretti, to mention but a few. In some of them, such as his long poem: "For the Time Being: A Christmas Oratorio" (1944), the brief "Autumn Song" (1936), and a piece of heightened prose: "Jacob and the Angel" (1939), the Anglo-American poet included angels who play relevant roles in the characters' or in the lyric speakers' lives, so much so that Christopher Isherwood, Auden's literary mentor and intermittent partner, declared that when they collaborated he needed to keep a sharp eye on his friend because "If Wystan had his way he'd make our plays nothing but choruses of angels" (Burt and Brooks-Motl 24) ${ }^{3}$. Moreover, Randall Jarrell comments that "the first semidramatic piece that Auden wrote without Isherwood was an oratorio about the birth of Christ" in which angels abound (Burt and Brooks-Motl 24). Therefore, it is somewhat striking that in

\footnotetext{
${ }^{1}$ Even though MacNeice never became as overtly political as some of his friends, he expressed his opposition to totalitarianism.

${ }^{2}$ Apart from these poets, Auden worked with Christopher Isherwood and Chester Kallman, who became his partners during different periods of his life (See Berg and Freeman 316-326, and Thekla Clark, 1996).

${ }^{3}$ Stephen Burt and Hannah Brooks-Motl quote Isherwood's words from "Some notes on Auden's Early Poetry", New Verse (November 1937): 4-9, reprinted in Monroe Spears, ed. Auden: A Collection of Critical Essays. Englewood Cliffs, N. J.: Prentice Hall, 1964, pp. 10-14.
} 
"Autumn Song", the poem to which I will dedicate much of the analysis in this article, the speaker declares that "the angel will not come" (Auden, v.16 ${ }^{4}$ ) to Earth, with the consequences that this entails for humankind, but more specifically for the poet.

The main objective of this article is to analyze the notions of poetry and poetic language proposed by W. H. Auden from his perspective of crisis or decline of modern culture not only by reviewing a selection of essays in which the poet explains his own ideas of poetry, but also by interpreting "Autumn Song", a poem where an absent angel, the paralysis of living creatures and the dominant silence show the limitations of human language when trying to account for reality and personal experiences. Although the figure of the celestial spirit, the autumn season in which the poem is framed and the images of disenchantment are key to its interpretation, it is essential to consider the religious and philosophical ideas that Auden developed during his career, which allow us to better understand his poetics. I argue that although Auden clearly acknowledges the limitation of words, he finds in poetic language a possible way to know and explore what it means to be human with all the mystery of it.

From 1922 - when Auden began writing poems -, until the 1970s, the AngloAmerican poet did not stop expressing his ideas about poetry and the poet. In 1963, he declared that "every work of art is, in one sense, a self-disclosure" (Mendelson, Complete Works, Vol. V, xiii), and the content, variety, and amount of his publications constituted the evidence of this thought. When Auden's five-year period as Professor of Poetry at Oxford ended in 1961, the poet hoped he could lead a more private life; nevertheless, as Edward Mendelson - editor of most of Auden's works - comments, "he began to say more in public about his inner self and his private history than he had ever done before" (Mendelson, Complete Works, Vol. V, xiii), until his death in 1973 at the age of sixty-six. As a result of his work, intertwined with his personal experiences, he developed an insightful and original Audenian poetics that, despite some contradictions, is worth studying, since it is a meaningful contribution to twentieth-century poetry studies.

After Auden immigrated to America early in 1939, he devoted many of his writings to literary criticism, publishing quite influential books, such as The Enchafèd Flood (three

\footnotetext{
${ }^{4}$ From here on I will refer to a verse or verses of the poem rather than to pages, by using v. or vv.
} 
Artículo. Paula Baldwin Lind. “And the angel will not come': W. H. Auden and the Paradox of Poetic Language".

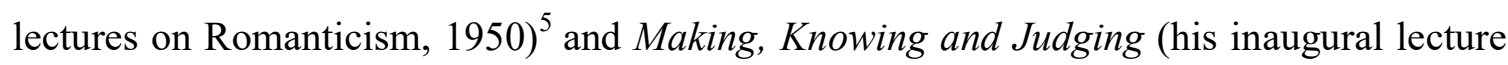
at Oxford, 1956). He also wrote introductions to books, specialized articles and essays, as well as reviews for various journals. These critical writings often deal with themes which recur in Auden's poetry and they provide valuable information on the view of life and the theory of art from which his poetry stems (Callan 79). In most of his theoretical works, Auden criticizes what he calls "the short-comings of contemporary theories of poetry" (Callan 80), which result from the limited scope of the key questions on which they are based. According to Edward Callan, one of his early critics,

Auden's own key questions leave no doubt of their metaphysical scope: "What is man? How does he differ from the gods on the one hand and from nature on the other? What is the divine element in man?" And he adds, significantly, that a different set of answers, or a shift of emphasis in the old answers to such questions "changes the style and subject matter of poetry and the poet's conception of his function" (Callan 80).

As the critic explains, Auden gave his own answers to these questions in "Criticism in a Mass Society" $(1941)^{6}$ where he analyzed two opposite notions man, which consider him as a fallen creature with a natural bias to do evil or, on the contrary, a human being who is good by nature and made bad by society. He argued that our acceptance of the first or the second statement is not just an academic option: "If, as I do, you assent to the first, your art and politics will be very different from what they will be if you assent, like Rousseau or Whitman, to the second" (Callan 80).

Auden thought that he was witnessing a collapse in civilization that he attributed, in part, to a diversity and differentiation that have their sources in the Renaissance and, especially, in the dualism of Descartes. Consequently, he believed that people tried, consciously or unconsciously to seek "some form of catholic unity to correct the moral, artistic, and political chaos that has resulted from an overdevelopment of protestant diversity (using these terms in their widest sense)" (Auden "Criticism in a Mass Society" 136). He argued that we differ, however, about the form that this unity should take because,

\footnotetext{
5 The Enchafèd Flood: or, The Romantic Iconography of the Sea is a book of three lectures by W. H. Auden, first published in 1950. The book contains Auden's 1949 Page-Barbour Lectures at the University of Virginia. ${ }^{6}$ This essay was much influenced by Auden's experiences in the 1930s, including Henri Bergson's ideas of open and closed societies in The Two Sources of Morality and Religion (1932), (Izzo, Auden Encyclopedia, 61
} 
in his view, this unity is metaphysical and is not to be found in a return to the Middle Ages. In fact, "[a]ttractive as the unity achieved by such an age may be, Auden does not see a return to it either possible or desirable" (Callan 83), an idea that he clearly expresses in his introduction to Poets of the English Language: "We must not, however, be nostalgic. Luther and Descartes, to whatever brink of disaster we have allowed them to push us, stand, like the angels about Eden, barring the way back from an unintelligible dualism to any simple one-to-one relation" (Auden and Pearson xxx).

Despite the negative comment that Auden makes regarding the influence of these European intellectuals on the Western Weltanschauung or worldview, he reckons that they have performed a role in our culture that is similar to that of angels in the garden of Eden ${ }^{7}$, since, from his perspective, they have prevented us from returning to a system that did not work. The angels the poet mentions are those who "emerge in Genesis 3 as animate cherubim, guardian angels armed with flaming swords east of Eden and, later, in upper Paradise, as charioteers of God" (Davidson xxiii) ${ }^{8}$. Auden will suggest later in many of his theoretical works and poems that despite the limited role of poetry in our society, the poet may perform a somewhat angelical function, as he "has a role of some importance and a duty, for he is urged, in the perilous times of 1939 [...] to make a vineyard 'of the curse' and, though he must sing of human unsuccess 'in a rapture of distress', he should 'teach the free man how to praise"” (Brooks 181-182) ${ }^{9}$.

In his rather pessimistic view of man's life within modern culture, Auden does not only diagnose the clash between unity and dualism but is deeply influenced by his reading of Søren Kierkegaard's existential writings, so much so that he concludes with the Danish philosopher that the basic human problem is "man's anxiety in time" (Auden, "A Preface to Kierkegaard" 214). He explains that this anxiety is in relation to man's past, present, and

\footnotetext{
${ }^{7}$ See The Book of Genesis 3: 24: "He drove out the man; and at the east of the garden of Eden he placed the cherubim, and a sword flaming and turning to guard the way to the tree of life." http://www.vatican.va/archive/bible/genesis/documents/bible_genesis_en.html\#Chapter\%203

${ }^{8}$ Davidson explains that the "two angels often identified as the angels of Eden are Metatron and Messiah (of the order of the cherubim), but Raphael is also regarded as the angel of the earthly paradise by virtue of his having guarded the Tree of Life" (30). The author mentions two writers who have assigned the role of guardians of Eden to different angels: in his State of Innocence, or The Fall of Man, John Dryden "concludes his dramatic poem, with Raphael hustling our first parents out of Eden", whereas John Milton assigns that function to Michael in his Paradise Lost (Davidson 30).

${ }^{9}$ The author quotes verses from Auden's "In Memory of W. B. Yeats" to show his point.
} 
Artículo. Paula Baldwin Lind. “And the angel will not come': W. H. Auden and the Paradox of Poetic Language".

future because at every moment he must freely choose one out of infinite possibilities. Moreover, in the Kierkegaardian interpretation that Auden adopts,

each choice is irrevocable, i.e. man has, both individually and socially, a history; what happens to him does not happen in time, but time itself happens in what he does. Hence his anxiety, for he can neither guarantee nor undo the consequence of any choice he makes. The power by which, without blinding himself to his anxiety, he is nevertheless still able to choose, is religious faith [...] (Auden, "A Preface to Kierkegaard" 78-81).

The previous statement is clearly in line with Auden's view of man as being essentially double by nature, but also with his conviction that despite being a unique creature, human beings cannot transcend time. It also shows that even though Auden still worked within a holistic framework - while he was living in America ${ }^{10}$ near the beginning of the Second World War - he began to experience an intellectual gradual change, which inspired him "to write poetry and essays that are explicitly Christian in language and substance" (Everett 66) ${ }^{11}$, a fact that may explain the presence of spiritual topics and angels in his works.

Later, in 1955 Auden published the first part of one of his seminal works: The Dyer's Hand and Other Essays (1962) ${ }^{12}$ - a collection of thirty four essays - where he attempts to answer questions related to the art of writing poetry and what it means for man's life: What is poetry about? and What is the poetic subject? He attempts to reply to these complex questions first by providing a possible definition of the nature of a poem: "A poem is a rite. [...] The form of a rite must be beautiful, exhibiting, for example, balance, closure and aptness to that which it is the form of. [...] In poetry the rite is verbal; it pays homage by naming" (Auden, The Dyer's Hand 57-58).

\footnotetext{
${ }^{10}$ Auden became an American citizen on May 20, 1946.

${ }^{11}$ In the 1940s, Auden began to use Kierkegaard's triad of categories: the aesthetic, the ethical, and the religious dimensions of man's existence in his works. Perhaps the four most representative poems of this period are: New Year Letter (1940), For the Time Being (1942), The Sea and the Mirror (1942-44), and The Age of Anxiety (1947).

12 The Dyer's Hand first appeared in three parts in The Listener, LIII. Part I (June 16, 1955), 1063-1066; Part II (June 23, 1955), 1109-1112; Part III (June 30, 1955), 1151-1154. Re-printed as single article in The Anchor Review: Number Two (New York, 1957), pp. 255-301.
} 
Six years later, he tried another answer to his literary concerns in "The World of the Sagas" (1968). In this brief essay he presents two Theophrastian ${ }^{13}$ character sketches of which the first is called "The Historian", who "wills to know the truth about the primary world [...] in which we are born, live, love, hate and die [...]"; and the second, called "The Poet", who desires "to make new secondary worlds of our own". Even though the first character personifies the "will-to-truth" and the second the "will-to-creation" (Auden, "The World of Sagas" 266), Auden warns us that both need the assistance of the other to function.

As I mentioned before, the Anglo-American poet develops his own poetic theory in numerous critical writings. When he ventures to define what poetry is - particularly in "Squares and Oblongs" (1948) - he often uses two analogies, which involve form and content. In the first case, he considers that writing a poem is analogous to achieving a perfect order; whereas in the second, it involves playing a game; thus, writing poetry implies following the rules of that game. Nevertheless, not any game becomes poetry, for this is a very specific activity: "a game of knowledge, a bringing to consciousness by naming them, of emotions and their hidden relationships" (Auden, "Square and Oblongs" 345). According to Callan, Auden understands games as free acts in which necessity is obeyed because it consists of rules chosen by the players. It is somewhat a "freely chosen aesthetic activity" (Callan 87). Regarding this notion of poetry as a game, Seamus Perry adds that it constitutes a recurring Audenian topic: "poetry as a highly specialized kind of game, a display of immense proficiency with its own formal demands and absorbing 'aesthetic-technical problems"” (Perry “Auden's Forms" 369). In fact, as Sean O'Brien explains, Auden gave great importance to form, thus using every stanza pattern imaginable: "ballad, cabaret song, canzone, Skeltonics, sonnet, villanelle, iambic or syllabic metre, and the rest" (O'Brien 359). In the following section of this article, I will focus in "Autumn Song", one of these poetic games, which is written in the form of a song where the figure of an absent angel can be associated to Auden's ideas of poetic language.

\footnotetext{
13 Theophrastus was the successor to Aristotle in the Peripatetic school.
} 
Artículo. Paula Baldwin Lind. “And the angel will not come': W. H. Auden and the Paradox of Poetic Language".

\section{The Angel in "Autumn Song": Image of the Absence of Words and Belief?}

According to David Leon Higdon and Mark C. Harper, "Now the leaves are falling fast', published in 1936, is surely one of the finest 'songs' [Auden wrote] and also one of its author's personal favorites, because he included it in every collection of his poems and twice recorded it" (423). Only after a series of revisions, in 1958 the poem acquired its title: "Autumn Song", a name that the poet preserved after the 1965 massive rewriting. This poem is included in "Twelve Songs", a collection that Auden wrote between 1935 and 1937.

Valentine Cunningham points out that Auden loved all kinds of music. It is no surprise, then, that his

poetic career should be one long effort to get his writing as close as could be to the condition of music. He poured out songs, ballads and lullabies. He collaborated with composers. One of his strongest poetic times was in the 1930s, writing love lyrics for Benjamin Britten to set [...]. He translated libretti into English and was a keen librettist in his own right $[\ldots](\text { Cunningham } \mathrm{n} / \mathrm{p})^{14}$.

His songs and ballads represent compositions of light verse (Pollnitz 78) ${ }^{15}$, a style that Auden combined with more sophisticated forms of poetry. He believed that this type of verse gave more freedom to the poet to express his feelings; thus, he found in the sixteenth and seventeenth centuries part of his musical inspiration, so much so that besides editing anthologies, special issues, collections, and other books, Auden was involved in the coedition of An Elizabethan Song Book, "produced in 1955 with Kallman and Noah Greenberg, who later collaborated with Auden on a medieval musical called The Play of Daniel" (Badenhausen 349). Moreover, his "love for the Elizabethan song is part of a larger

\footnotetext{
14 Auden provided the words for Britten in the American operetta Paul Bunyan, for Hans Werner Henze in Elegy for Young Lovers and The Bassarids, and for Stravinsky in The Rake's Progress.

15 The critic considers that many songs and ballads are the ones that best represent Auden's light verse. These are sometimes composed to the tunes of popular ballads ("Victor" can be sung to "Franky and Johnny") or of ribald university songs ("Miss Gee" can be sung to "St James Infirmary"); sometimes they draw on or parody the conventions of ballads, folk-songs and nursery rhymes as we have explained in the text, and sometimes they imitate the styles and rhythms of negro jazz and West Indian music ("Roman Wall Blues" and "Calypso").
} 
nostalgia for a not-too-specific time when the poet was accepted by a broadly based audience, for whom he therefore wrote light verse" (Badenhausen 76).

In terms of its musical form, “Autumn Song” is not merely part of Auden's lightverse compositions. When reading these verses, Matthew Mutter states that the poem takes, "at first glance, the form of a dark nursery rhyme that uses the change of seasons as an occasion for mythic sorrow" (69), a fact that Cunningham highlights when he tells that for Auden "nursery rhymes, kiddy doggerel and folk verse were the genetic stuff of poetry" (Cunningham n/p). ${ }^{16}$ The Anglo-American poet found in these simple musical configurations the ideal vehicle to speak about man's existential and psychological problems.

Following the poem's publication on the March $14^{\text {th }}$, 1936 issue of The New Statesman and Nation, Auden began to revise it for his Look, Stranger collection (also published in 1936). From the very beginning, the poem reveals the irresolution of two worlds: the past and future; the first is painful whereas the latter is uncertain.

"XXVIII" in The English Auden $\left(E A^{17}\right)$

Now the leaves are falling fast, Nurse's flowers will not last; Nurses to the graves are gone, And the prams go rolling on.

Whispering neighbours, left and right, Pluck us from the real delight; And the active hands must freeze Lonely on the separate knees.

Dead in hundreds at the back Follow wooden in our track, Arms raised stiffly to reprove In false attitudes of love.

Starving through the leafless wood Trolls run scolding for their food; And the nightingale is dumb, And the angel will not come.
“Autumn Song" in Collected Poems $(C P)^{18}$

Now the leaves are falling fast,

Nurse's flowers will not last,

Nurses to their graves are gone,

But the prams go rolling on.

Whispering neighbours left and right

Daunt us from our real delight,

Able hands are forced to freeze

Derelict on lonely knees.

9 Close behind us on our track,

10 Dead in hundreds cry Alack,

11 Arms raised stiffly to reprove

12 In false attitudes of love.

13 Scrawny through a plundered wood,

14 Trolls run scolding for their food,

15 Owl and nightingale are dumb,

16 And the angel will not come.

${ }^{16}$ Other folk-songs and nursery rhymes written by Auden are: "As I Walked Out One Evening" and "The Witnesses".

${ }^{17}$ From now on, I will use the abbreviation EA to refer to The English Auden and CP for Collected Poems when I quote verses from each version of the poem, as these are the books where the poem was published.

${ }^{18}$ This latest version of the poem includes the definite revisions. 
Artículo. Paula Baldwin Lind. “'And the angel will not come': W. H. Auden and the Paradox of Poetic Language".

Cold, impossible, ahead

Lifts the mountain's lovely head Whose white waterfall could bless

Travellers in their last distress.
17 Clear, unscaleable, ahead

18 Rise the Mountains of Instead,

19 From whose cold cascading streams

20 None may drink except in dreams.

Before analyzing the symbolism of the poem, it is interesting to refer to its process of composition and revision because it shows the importance that the Anglo-American poet gave to each word, even though in his theoretical works he constantly repeated that sometimes words lose their meaning and, consequently, they become lies. During some periods of his life, Auden was obsessed with revisions. Furthermore, in Mendelson's view, for Auden, "[t]he acts of revision performed in secret by a poet were acts of compulsion" (Mendelson, "Revision and Power" 104). To an extent, his revisions before and after the publication of his works, constitute one of the means by which he put his theory into practice: "Auden understood that revision was an act of power over his own text, and he therefore revised his texts in ways that renounced the kind of power that he employed in revising. He recognized that when he - like any other writer - altered the words on a page, he was using his authority to manipulate, transfer, alter, or eliminate" (Mendelson, "Revision and Power" 103).

In the case of "Autumn Song", after its 1936 first publication, Auden introduced some changes for his Look, Stranger collection (also 1936) by adding two commas (v. 5), deleting two commas (vv. 13, 18), and changing "our back" (v. 9) to "the back" and "waterfalls" (v. 19) to "waterfall" (Higdon and Harper 424). During the next twenty-two years the text remained stable in all its publications: Selected Poems (1938), Some Poems (1940), The Collected Poetry (1945), and Collected Shorter Poems (1950). Nevertheless, when the poet prepared his poems for the Penguin selection in 1958, he introduced other changes: the definite article "the" became "their" (v.3) and "our" (vv. 6, 7, 8) in four different lines. During the summer of 1965, Higdon and Harper explain that, as the author prepared a copy for The Collected Shorter Poems 1827-1957 (1966), “Auden shattered this textual stability and subjected his poem to a revision so thorough as to constitute a rewriting. Only six of its twenty lines retained their 1936 form" (Higdon and Harper 425). An illustrative example of this process is seen in line 15. In the original it says: "And the nightingale is dumb" (v.15 EA), a verse paired with "And the angel will not come" (v.16 
$E A \& C P$ ), but Auden creatively returned to the nursery scene of the poem's opening stanza and changed the line to: "Owl and nightingale are dumb" (v.15 CP). The revision, according to the same critics, "is particularly resonant not only because of its allusions to the nursery rhyme birds, but also to the emblems of wisdom and art potentially present in all contrasts between these two birds in English poetry since 'The Owl and the Nightingale' (c. 1189-1216)" (Higdon and Harper 425). However, the same critics argue that in Auden's revised version "neither learning nor art assists the individual, and the original hint of the withdrawn supernatural figure disappears altogether" (425). The most radical revision, however, occurred with the substitution of a new stanza for the 1936 original last one; by doing so, Auden withdrew hope and salvation from the scene: "the waterfall which had the volitional capacity to 'bless' now becomes 'cascading streams' totally unavailable except in 'dreams"' (Higdon and Harper 426).

As I have already announced in the introductory section of this article, I will focus on three elements present in "Autumn Song" in order to infer Auden's idea of poetic language. First, the season; that is to say, autumn as a framework for the history of man; then, the possible meaning of the angel within the poem, and finally, the images of disenchantment or what I call, the "disillusionment of words", that is to say, when language cannot express or communicate an experience or describe a reality.

The poem begins with the image of leaves that are falling, a rather conventional representation of the season, which Auden introduces as if it were an indifferent situation. Mutter thinks that these lines "present a mythic situation: human decay takes place against a natural backdrop of enduring seasonal repetition" (Mutter 69). In the critic's interpretation, the poem shows the repetitive mythical cycles that Theodor Adorno and Max Horkheimer describe: "Like magical rites, myths signify self-repetitive nature, which is the core of the symbolic: a state of being that is presented as eternal, because it incessantly becomes actual once more by being realized in symbolic form" (17). I believe that this is precisely what happens within the world of the poem: as the leaves keep falling each autumn, it seems that all other movements stop, that time stands still, as Auden vehemently asks in one of his funeral blues - "Stop all the clocks [...]" (Auden, "XXXIV" The English Auden 163) - also written in 1936 just a month after "Autumn Song". The activities that nurses, neighbours, lovers, trolls, owls, nightingales, soldiers, and travellers perform also 
Artículo. Paula Baldwin Lind. “And the angel will not come': W. H. Auden and the Paradox of Poetic Language".

"fall" and come to nothing. Furthermore, even the anonymous angel does not descend (fall) from Heaven. Paradoxically, while living creatures - human and spiritual - are paralyzed, the cycles of nature follow their course.

The nature metaphor expands in the rest of the poem and weaves different meanings. The fourth stanza shows the peak time of shedding all the leaves, so that the new leaves will come in a somewhat incessant process of regeneration. In a remote past or ideal state of man the poem seems to refer to, all these leaves used to feed animals and birds, but now they are "[s]tarving through the leafless wood" (v.13 EA). In the final version of the poem Auden changed this line for "[s]crawny through a plundered wood" (v.13 $C P$ ), thus making the situation of surviving creatures more tragic. The leaves in this version have not fallen as part of their natural cycle, but someone or something has stripped the trees of them. In such lifeless and hopeless condition, neither the birds will sing, nor the angel will come. As we have said before, the revised version adds a dumb owl to line 15, which, apart from the contrast that it establishes between the owl and the nightingale, is pivotal to the interpretation of the poem.

Regarding the symbolism of the owl, J. E. Cirlot explains that in "the Egyptian system of hieroglyphs, the owl symbolizes death, night, cold and passivity. It also pertains to the realm of the dead sun, that is, of the sun which has set below the horizon and which is crossing the lake or sea of darkness" (Cirlot 247). In Ancient Greece owls were associated to Athena, the goddess of wisdom, whereas in Rome the bird was dreaded as an omen of doom. With respect to the nightingale, the strands of meaning woven round the symbolism of this bird are infinite and usually stem from two traditions: Greek and Latin poetry. In Homer's Odyssey, a mother plotting to kill the son of another makes a mistake and kills her own, thus is turned into a nightingale. In Book VI of Ovid's Metamorphoses retells the popular version of the myth where he states that Procne, who was married to Tereus, bore him a son that was called Itys. Nevertheless, her husband desired her wife's sister Philomela, and raped her. After this, his wife was transformed into a swallow and the young woman into a nightingale, yet one that could not sing because the rapist had cut out her tongue (Chandler 78-84) ${ }^{19}$. In terms of the hermeneutics of Auden's poem, it is relevant

\footnotetext{
${ }^{19}$ There are many versions of the myth after Ovid. Critics discuss whether Philomela or her sister, Procne, became the nightingale. Since Ovid's Metamorphoses it has been generally accepted that Procne was
} 
to know that in nature the female nightingale is mute and only the male of the species can sing; therefore, the bird in the poem can be either the female nightingale who has never been able to warble or the male bird who, despite having the capacity to sing, has been silenced by the horrors that he has witnessed -"Nurses to their graves are gone" (v. $3 C P$ ); "Dead in hundreds cry Alack" (v. $10 E A \& C P$ )-, and the consequences of war and starvation (see verse 13 in both versions).

Even though both birds sing at night and by nature the owl's dismal song is usually contrasted to the mellifluous tune of the nightingale, the violence associated with the myth has led poets, especially during the Romantic period, to interpret this bird's melody as a sorrowful and melancholic lament; nevertheless, Auden is quite critical regarding romantic theories of poetry. I will address the nightingale's song and its meaning in relation to Auden's view of poetic language in the section dedicated to Auden's ideas on poetry and its role in society.

Clearly, autumn is not only a season in this poem, but also a transition, the passing of time along with the meaning of life. For the poet, autumn symbolizes departure of old things and the coming of new ones, yet the problem is that the lapse of time between these two transitional phases produces a feeling of hopelessness, which is shown in the appearance of soldiers with "arms raised stiffly to reprove" (v.11EA\& $C P$ ) in the third stanza. They (the dead) walk expressionless - "Follow wooden in our track" (v.10EA) -, as if they could not avoid their fatal destiny.

Seamus Perry argues that Auden's Thirties poetry is full of falls. In fact, it is possible to state that autumn in this poem - the fall of leaves - is within the frame of other falls: man's fall into evil, war, and death; “everything, leaves and all, should be in on some great falling movement, as though the world at large were being dragged to its catastrophe by a force as ineluctable as gravity [...].” (Perry, “Auden Unparadized” 72). In the critic's view the decline and collapse of modern culture that Auden wants to show goes through stages like "[a] duplicated comedy of gravitational pull: first the leaves, and then the monstrous, startlingly autonomous, prams; the dull rhyme on 'on' [in the first stanza]

transformed into a nightingale and Philomela into a swallow. The English romantic poet John Keats argued that although Philomela was tongueless, she was turned into a nightingale, and Procne into a swallow. 
Artículo. Paula Baldwin Lind. “And the angel will not come': W. H. Auden and the Paradox of Poetic Language".

communicates their irresistible progress with a wonderful obduracy" (Perry, "Auden Unparadized" 72).

If everything tends to fall in this poem, why then does the mysterious angel not come down to Earth from Heaven? Who is this angel? As I explained at the beginning, angels are present in a number of works by Auden, but the angelic figure that he presents is "Autumn Song" is quite enigmatic. In the context of the poem no one seems to be waiting for anyone or anything; rather, the indifferent and busy inhabitants of the human world keep on struggling to survive to the decline of that same world; they are hopelessly certain that "[...] the angel will not come" (v.16 EA \& $C P)$.

In Sacred Scriptures, most angels are messengers of God who bring tidings, prevent from dangers, reveal hidden truths, or guide men in their path to salvation, but the "Clear, unscaleable, ahead / Rise the Mountains of Instead" (vv.17-8 CP), is an obstacle almost impossible to overcome. Silence invades everything, except for "the prams [that] go rolling on" (v. $4 A E \& C P$ ), or the "Trolls [that] run scolding for their food" (v.14 CP). According to Mutter,

all that remains are the 'Mountains of Instead', the presence of which disenchants the quest narrative in which the hero seeks or passes through the mountains. 'Instead' is a state of free choice and action; it registers human possibility rather than mythic necessity. There may be no 'instead' to counter the decay of nurses and their flowers, but there is for the 'Dead' who 'cry Alack (70).

Auden's angel does not seem to be able to descend to this world. It is definitely not a redeeming angel like Michael, who was sent by Pope Gregory the Great to save Rome from the plague (Jones 108), or a healer like Raphael, not even Gabriel the Herald, because if he does not come, no message needs to be delivered. Furthermore, the absence and silence of this mysterious angel posits more questions because "[i]n Judaism, Christianity, and Islam, angels are seen as messengers from God. This is seen in many passages in the Hebrew Scriptures, in the New Testament, in the Talmud, and in the Quran. When God has a message, he sends an angel to deliver it" (Jones 62) to men. Nonetheless, in Auden's "Autumn Song", there is no contact of the angel with any man on Earth; thus, communication becomes impossible. The angelic silence is extended to other creatures and 
regardless of the second word in the title of the poem: "Song", neither the humans (nurses, neighbours, dead, travellers), nor the mythological creatures (trolls), or the birds (owl and nightingale) speak or chant. So, which is the song in the poem? Is it the melody of withered inanimate autumn leaves? Does nature still sing in this devastated landscape?

In an article that was published in The Independent (UK) in 2004, Stephen Fry, Ian McKellen and Melvyn Bragg bring to their memory an occasion when Auden was asked whether he would get rid of his demons through poetry, to which he replied: "No, no, I don't want to get rid of my demons, or my angels would fly away too" 20 , a statement that Rainer Maria Rilke had used previously ${ }^{21}$, linking his lack of poetic inspiration to the angels' departure, as well as to a human longing for a presence. Yet, what sort of presence?

Alan Jacobs states that Auden was raised in the Church of England, probably due to his mother's devotion; however, "by the time he came to Oxford in 1925, [he] had been an unbeliever for at least three years" (Jacobs 170) and this condition lasted for about another decade. He returned to his faith via the United States' Episcopalian branch in 1940 as the previous year he had moved to New York. In the early 1940s he became a good friend to Reinhold Niebuhr, leading American twentieth-century theologian. During this period not only Niebuhr, but also Sören Kierkegaard, - as I have explained at the beginning of this article - were probably the greatest religious influences on him. Arthur Kirsh points out that it was around 1947 when Auden joined a small ecumenical congregation called "The Third Hour", as well as a group of Episcopal scholars. When Ursula Niebuhr asked him about his ideas on theology, the poet replied: "Re my theological position, it is I think the same as your husband's, i.e. Augustinian not Thomist, (I would allow a little more place, perhaps, for the via negativa)" (Kirsh xvi). In fact, as Kirsh emphasizes, Auden "constantly referred to, reviewed, or echoed such writers as Saint Augustine, Pascal, Søren

\footnotetext{
${ }^{20}$ See https://www.independent.co.uk/arts-entertainment/books/news/stephen-fry-ian-mckellen-and-melvynbragg-share-stories-of-how-literature-can-help-with-mental-a6830516.html

${ }^{21}$ See Arthur Freeman, "The Poetry and Spirituality of Rainer Maria Rilke. Compiled and with introduction and some translation". Moravian Theological Seminary, Bethlehem, PA: https://www.moravianseminary.edu/sites/ms/files/files/documents/2017-04/RainerRilke_Intro.pdf

Rilke regarded his poem "Turning point" "as representing an important development in his understanding of things" (Stephen Mitchell, The Selected Poetry of Rainer Maria Rilke 133-134). The title in German is "Wendung" and it was written after four years of depression and failed poetic productivity following the publication of The Notebooks of Malte Laurids Brigge. Rilke had considered psychoanalysis, but was afraid of it because he thought that "if my devils were driven out my angels also would receive a slight, a very slight (shall we say) shock, and, you see, I cannot let it come to that pass at any price" (See Selected Letters of Rainer Maria Rilke 1902-1926, 204).
} 
Artículo. Paula Baldwin Lind. “And the angel will not come': W. H. Auden and the Paradox of Poetic Language".

Kierkegaard, Martin Buber, Paul Tillich, Reinhold Niebuhr, and Eugene RosenstockHuessy [...]" (13). Auden's preference for St. Augustine of Hippo (354-430) rather than for St. Thomas of Aquinas (1225-74) is extremely relevant to understand his notion of angels and poetic language, as I will explain in a few more lines.

In broad terms, the via negativa approach ("negative way" or via negationis) postulates that by saying what God is not, it is possible to gain a better comprehension of what $\mathrm{He}$ really is because language is always inadequate and insufficient to describe the ineffable, namely, the attributes of God. In linguistic terms, it entails a mode of affirmation by denial, which Auden used, in part, to make his readers work. He did not consider himself a mystical and at the beginning of his career he was quite sceptical about the value of Christian mysticism. In the Introduction he wrote for The Protestant Mystics (1964), a book on which he collaborated with Anne Fremantle, Auden writes that many who have achieved the vision of God are "those who have chosen the Via Negativa" (Auden, "Introduction to The Protestant Mystics" 61), and then reveals the mystical experience he had in 1933, which later he described in his poem: "A Summer Night 1933",22. In the above mentioned Introduction, Auden declared that even though his experience was not a revelation of God, but rather an awareness of the value of others, he felt himself "invaded by a power which, though [he] consented to it, was irresistible and certainly not [his]" (Auden, "Introduction to The Protestant Mystics" 58). His was a vision of Agape, which he considered multiple; that is, comprising "a multiplicity of persons; like the Vision of Eros, it involves human persons only; like the Vision of God it is of a mutual relation; but unlike any of the others, this relation is a relation between equals" (Auden, "Introduction to The Protestant Mystics" 58-59).

In addition to this Augustinian feature (that is not exclusive to the saint), Auden borrows other ideas from the saint's works that are related to the notion of Agape and elucidate one of the preoccupations that the Anglo-American poet expresses in many of his writings: the difficult aspiration to the fusion of Eros and Agape in the concept of Christian charity. If these two visions involve only humans who are equals, then the chance of seeing and of speaking to and angel is almost unthinkable, since these creatures are purely spiritual and inhabit the invisible world. Nevertheless, Augustine defines angels mostly and

${ }^{22}$ Auden wrote an earlier and longer version of the poem entitled by its first line: "Out on the lawn I lie in bed". 
precisely by their "ministrations"; that is, by their role or function both in the invisible and visible world rather than exclusively by their spiritual nature:

The Angels are spirits, but it is not because they are spirits that they are Angels. They become Angels when they are sent, for the name Angel refers to their office not to their nature. You ask the name of this nature, it is spirit; you ask its office, it is that of an Angel, [i.e., a messenger]. In as far as he exists, an Angel is a spirit; in as far as he acts, he is an Angel (St. Augustine, En. in Ps. 103, 1,15: PL 37, 1348) ${ }^{23}$.

If these celestial beings are made visible only when God sends them on a mission and Auden's angel will not come, then how could the inhabitants of the world of the poem establish contact with him? Why has this angel not received a mission? Are the nurses and the rest of the living visible creatures unable to interpret a divine message?

St. Augustine did not resolve the question of angels' speech, though he observed that God does not speak to the angels in the way that we speak to each other or to God because He speaks without sound. Therefore, the common ground between men and angels does not seem to be language or words, but the fall and the silence after it. Like men, angels committed sin; nevertheless, while Aquinas claimed that angels only sinned by pride and envy, Augustine includes carnality, a quite conflictive element for Auden, which he apparently could not solve either in his life or in his works. I think that there is a clear sexual innuendo in both versions of the second stanza of "Autumn Song" when the speaker refers to the situation of some persons, probably two lovers, whose sensual game is interrupted by the neighbours who start whispering - as if they were gossiping - when they see them having pleasure:

Whispering neighbours left and right

Daunt us from our real delight

Able hands are forced to freeze

Derelict on lonely knees (vv. 5-8 CP).

In such pitiable condition, human beings are frustrated as they cannot experience pleasure; furthermore, as the characters in the poem intuitively know that the angel will not

${ }^{23} P L$ refers to the Patrologia Latina edited by J. P. Migne. See Bibliography. 
Artículo. Paula Baldwin Lind. “And the angel will not come': W. H. Auden and the Paradox of Poetic Language".

come, nothing is left for the survivors of the world that Auden depicts in "Autumn Song". Neither in Auden's city or in the woods the birds will chant, nor any spell of the magic bond will work because people do not believe any more in the aid of supernatural creatures.

In Auden's perspective, humankind will not be restored by a celestial being. The absent angel could be interpreted as the impossibility of salvation - of being rescued from the decay of modern society represented by the autumnal season -, but also as the lack of religious belief or hope. However, in the context of silence and fall that frames the poem, the image of the angel could be linked more directly to the absence of poetic inspiration, to the lack of adequate words, thus to the failure of communication.

\section{Auden's Notion of Poetry and Poetic Language}

At the time Auden wrote "Autumn Song”, Western civilization was in a somewhat autumnal season, haunted by the terrible outcome of the First World War and only months before the beginning of the Spanish Civil War. Modern society had no hope of a new redemption and the poem's city becomes a place of yearning, of hunger and desperation. Cleanth Brooks classifies Auden as the poet of civilization; "He loves landscapes, to be sure, and confesses that his favorite is the rather austere landscape of the north of England, but over and over he has told us that the prime task of our time is to rebuild the city, to restore community, to help re-establish the just society" (Brooks 173). Nevertheless, in "The Poet and the City" (1962) Auden laments that the poet's status has lost his public influence because the fine arts have lost the social utility they once had; "in the purely gratuitous arts, poetry, painting, music, our century has no need" (Auden, "The Poet and the City" 75). A few pages later, he declares what he thinks is one of the main reasons of man's decay: "the loss of belief in the eternity of the physical universe [,] in the significance and reality of sensory phenomena [,] in a norm of human nature which will always require the same kind of man-fabricated world to be at home in [, and] the disappearance of the Public Realm as the sphere of revelatory personal deeds" (Auden, "The Poet and the City" 78). As a result, according to Auden, the poet's vocation is much more difficult to exercise, as sometimes poetry may not have any effect in the lives of the citizens.

From early in his intellectual development, as Mutter comments, Auden 
was influenced by a variety of magical ontologies, including the neopagan blood mysticism of D. H. Lawrence, the Orphic poetics of Rainer Maria Rilke and the tragic occultism of W. B. Yeats. He also read deeply in unconventional anthropology of religion that pursued not so much scientific explanations of the sacred as the sacred itself and in psychoanalytic theories that emphasized the creative unconscious. As Auden developed as a poet, however, he became more and more convinced that magical poetics were based on an untenable response to secular modernity and misguided conceptions of language (Mutter 59).

In his 1939 poem, "In Memory of W. B. Yeats", Auden expresses his ideas on the functions of poetry:

[...] For poetry makes nothing happen: it survives

In the valley of its making where executives

Would never want to tamper, flows on south

From ranches of isolation and the busy griefs,

Raw towns that we believe and die in; it survives,

A way of happening, a mouth (Auden, Collected Poems II, 248).

The statements in the poem about the function of poetry are contradictory at first sight, since on the one hand, the poet announces that "poetry makes nothing happen", yet on the other, he says that it is a "way of happening". Gareth Reeves comments that "perhaps especially, in the face of his espousal of Christianity in 1940, he needed to demonstrate, to himself as much as to his readers, the nature and importance of poetry's particular way of happening" (Reeves 188-189). According to Mutter, Auden intended to assert that poetry was "equally a game of acknowledgement, a recognition of finitude and error. In it, you discover a self, [...] 'who is not a dream amenable to magic but the all too solid flesh you must acknowledge as your own"” (Mutter 78). The critic believes that the Anglo-American poet considered that "Art is not Magic [;] its proper effect, in fact, is disenchanting" (Mutter 59), thus poetry's particular "way of happening" would not be a magical means to induce emotions; on the contrary, by considering it a way of knowing, Auden is disenchanting poetic genre. It is extremely important not to remove or isolate the maxim - "poetry makes nothing happen" - from this stanza because it can only be fully understood in the context of the rest of the poem. In fact, poetry "survives /In the valley 
Artículo. Paula Baldwin Lind. “And the angel will not come': W. H. Auden and the Paradox of Poetic Language".

[...]" (Auden, Collected Poems II, 248) and has definitely a way of happening through "a mouth". Besides, not all things that happen have an instrumental purpose, an idea that Auden developed later in "The Poet and the City", as I have briefly mentioned before.

Jo-Anne Cappelutti suggests that, to an extent, Auden's commitment "aligns with his desire to save poetry from serving as a substitute 'religion', as secular or religious dogma that tells the reader what to think - rather than give him or her something to think about" (4). Despite the terrible times described in "Autumn Song" and the silence provoked by human fall and failure, the poet must offer an aesthetic experience, that of teaching to hear one's imagination, which is achieved only in "dreams" (v. $20 C P$ ). Even though Auden trusts the authenticity of imagination as many romantic poets did, he distances himself from the idealistic vision of the poet as a nightingale who sings and cheers men with his melody. The tradition that links bird song with poetry goes back to classical literature and reached its highest development during the Romanticism, especially in England. Most nineteenth-century British poets - Charlotte Smith, William Wordsworth, S. T. Coleridge, P. B. Shelley, and John Keats - believed that the nightingale was a kind of muse that inspired the poet and soon the metaphors and symbols associated to the song of the bird were translated and interpreted in relation to poetry and poetic language. Within the romantic tradition, the singing bird embodied the poet's idealization of his art because writer and nightingale became identified in such a way that P. B. Shelley declared that "A poet is a nightingale, who sits in darkness and sings to cheer its own solitude with sweet sounds" (11). The paradox is that in Auden's "Autumn Song” the bird is absolutely mute, perhaps because he has nothing true to say, for as Auden emphatically declared in The Dyer's Hand: "In so far as poetry, or any other of the arts, can be said to have an ulterior purpose, it is, by telling the truth, to disenchant and disintoxicate" (Auden, The Dyer's Hand 27).

Mark S. Burrows reinforces the relevance of truth in art in his article on "Mysticism, Poetics, and the Unlanguageable", when he brings up Georg Gadamer's theory of art in Truth and Method:

Does not the experience of art contain a claim to truth which is certainly different from that of science, but equally certainly is not inferior to it? And is it not the task of aesthetics precisely to provide a basis for the fact 
that artistic experience is a mode of knowledge of a unique kind... [which is] certainly different from all moral rational knowledge and indeed from all conceptual knowledge, but still knowledge? (Burrows 173).

So, in the words of Gadamer that Burrows highlights, and from the point of view of the Anglo-American author, poetry as art would entail a different way of "happening" that that produced by science; thus, it would become another way of knowing.

\section{Conclusion}

Poets live and work at the margins of the inarticulate. The angel in "Autumn Song" could symbolize inspiration or the figure of a muse that provokes that inspiration. It is clear that when he does not come, silence invades the world. A similar situation occurs in the case of the mute nightingale who does not sing his melodious song. However, I think that the interpretation of the angel's absence goes beyond the idea of the poet's lack of inspiration or poetic imagination, as it shows an existential state of spiritual emptiness and the notion of crisis of modern civilization that the poet frequently addresses in his poetic and theoretical works. At the end, the poem winds its way towards a rather pessimistic outcome, particularly in the definite version, in which, as I have already noted, the waters that used to "[...] bless / Travellers in their last distress" (vv. 19-20 EA) have been transformed into "[...] cold cascading streams / None may drink except in dreams" (vv. 19$20 \mathrm{CP}$ ), with a final line that is quite ambiguous, as dreams could also refer to the power of poetic imagination. Furthermore, despite the fact that leaves will fall time and again each autumn and the ritual of death and rebirth will be repeated in nature, the absence of the angel, of this divine presence, will increase man's feeling of loneliness, as he can neither speak, nor love: "And the active hands must freeze / Lonely on the separate knees" (vv. 7-8 $E A)$. The act of love, as I suggested before, is interrupted by "Whispering neighbours left and right [who] Daunt us from our real delight" (vv. 7-8 CP).

Burrows clearly explains that

in this raiding of what we cannot speak, [the poet's] vocation embodies a longing for, a reaching toward, what we cannot manage with our minds alone, the endless working with words which [T. S. Eliot expresses in two 
Artículo. Paula Baldwin Lind. “And the angel will not come': W. H. Auden and the Paradox of Poetic Language".

verses:] 'after speech, reach/ Into the silence'. Poets are the artists of the imagined, drawn into and through language by that which lies within yet always beyond the grasp of speech (121).

Regardless of the limitations of language - the disillusionment of words - to describe reality and express the ineffable, poetry is a way of knowing and exploring the mystery of being human. Undoubtedly, "Auden commits himself to writing a poetry that makes this Nothing happen" (Cappelutti 4) and in this way, he acknowledges - at the same time - the limitation of words and the power of poetic language to know the world and what we are. There is an intense humanity in W. H. Auden's poetry, a sense that not only language is weak and inadequate to express our innermost experiences, but that we are weak and needy. Because of this and given the relevant role that the Anglo-American poet had in the history and development of twentieth-century poetry and poetic theory, conducting a study on Auden today is a contribution to scholarly studies of English Literature.

\section{REFERENCES}

Adorno, Theodor and Max Horkheimer. Dialectics of Enlightment. Trans. John Cumming. New York: Continuum, 2000. Print.

Auden, W. H. "A Preface to Kierkegaard." The Complete Works of W. H. Auden. Prose: 1939-1948. Ed. Edward Mendelson. Vol. II. New Jersey: Princeton University Press, 2002. 213-217. Print.

Auden, W. H. "Autumn Song." W. H. Auden: Collected Poems. Ed. Edward Mendelson. Revised edition. London: Faber \& Faber, 1991. Print.

Auden, W. H. "Criticism in a Mass Society." The Intent of the Critic. Ed. Donald A. Stauffer. Princeton: Princeton University Press, 1941. Print.

Auden, W. H. Forewords and Afterwords. New York: Vintage, 1989. Print.

Auden, W. H. "In Memory of W. B. Yeats." W. H. Auden: Collected Poems. Ed. Edward Mendelson. Revised edition. London: Faber \& Faber, 1991. Print.

Auden, W. H. "Introduction to The Protestant Mystics." The Complete Works of W. H. Auden. Prose: 1963-1968. Ed. Edward Mendelson. Vol. V. New Jersey: Princeton University Press, 2015. 42-65. Print.

Auden, W. H. "Squares and Oblongs." The Complete Works of W. H. Auden. Prose: 19391948. Ed. Edward Mendelson. Vol. II. New Jersey: Princeton University Press, 2002. 339-350. Print.

Auden, W. H. The Dyer's Hand and Other Essays. New York: Random House, 1962. Print.

Auden, W. H. "The Poet and the City." The Dyer's Hand and Other Essays. New York: Random House, 1962. 72-89. Print. 
Auden, W. H. "The World of the Sagas." The Complete Works of W. H. Auden. Prose: 1963-1968. Ed. Edward Mendelson. Vol. V. New Jersey: Princeton University Press, 2015. 266-289. Print.

Auden, W. H. "Writing." Auden, W. H. The Dyer's Hand and Other Essays. New York: Random House, 1962. 13-30. Print.

Auden, W. H. "XXVIII" ("Autumn Song"). The English Auden. Poems, Essays and Dramatic Writings: 1927-1939. Part IV: Poems 1931-1936. Ed. Edward Mendelson. London and Boston: Faber \& Faber, 1977. Print.

Auden, W. H. "XXXIV" ("Stop All the Clocks"). The English Auden. Poems, Essays and Dramatic Writings: 1927-1939. Part IV: Poems 1931-1936. Ed. Edward Mendelson. London and Boston: Faber \& Faber, 1977. Print.

Auden, W. H. and N. H. Pearson, Poets of the English Language. Langland to Spenser. 5th. Vol. I. New York: The Viking Press, 1950. Print.

Badenhausen, Richard. "Double Take: Auden in Collaboration." Auden in Context. Ed. Tony Sharpe. Cambridge: Cambridge University Press, 2013. 347-358. Print.

Berg, James J., and Chris Freeman. "Auden and Isherwood." W. H. Auden in Context. Ed. Tony Sharpe. Cambridge: Cambridge University Press, 2013. 316-326. Print.

Brooks, Cleanth. "W. H. Auden as a Critic Author." The Kenyon Review 26.1 (1964): 173189. Print.

Burrows, Mark S. "Raiding the Inarticulate: Mysticism, Poetics, and the Unlanguageable." Spiritus: A Journal of Christian Spirituality 4.2 (2004): 173-194.Print.

Burt, Stephen and Hannah Brooks-Motl. Eds. Randall Jarrell on W. H. Auden. New York: Columbia University Press, 2005. Print.

Callan, Edward. "The Development of W. H. Auden's Poetic Theory since 1940." Twentieth Century Literature 4.3 (1958): 79-91. Print.

Cappelutti, Jo-Anne. "Making Nothing Happen: W. H. Auden's Romantic Legacy." Renascence 66.1 (2014): 3-23. Print.

Chandler, Albert R. "The Nightingale in Greek and Latin Poetry." The Classical Journal 30. 2 (1934): 78-84. Print.

Cirlot, J. E. A Dictionary of Symbols. Trans. Jack Sage. London: Routledge, 1971. Print.

Clark, Thekla. Wystan and Chester: A Personal Memoir of W. H. Auden and Chester Kallman. Columbia University Press, 1996. Print

Cunningham, Valentine. "Auden and Song." British Library. 25 May 2016. Web. 13 September 2019. <https://www.bl.uk/20th-century-literature/articles/auden-andsong>.

Davidson, Gustav. A Dictionary of Angels, Including the Fallen Angels. New York: The Free Press, 1967. Print.

Everett, Barbara. Auden. Edinburgh: Oliver and Boyd, 1969. Print.

Higdon, David Leon and Mark C. Harper. "Auden 'Abandons' a Poem: Problems with Eclectic Texts." Text 7 (1994): 423-434. Print.

Hynes, Samuel L. The Auden Generation: Literature and Politics in England in the 1930's. London: The Bodley Head, 1976. Print.

Izzo, David Garrett. W. H. Auden Encyclopedia. North Carolina: McFarland and Co., 2004. Print.

Jacobs, Alan. “Auden's Theology." Auden in Context. Ed. Tony Sharpe. Cambridge: Cambridge University Press, 2013. 170-180. Print.

Jones, David Albert. Angels: A History. Oxford: Oxford University Press, 2010. Print. 
Artículo. Paula Baldwin Lind. “And the angel will not come': W. H. Auden and the Paradox of Poetic Language".

Kirsch, Arthur. Auden and Christianity. New Haven and London: Yale University Press, 2005. Print.

Mendelson, Edward. "Revision and Power: The Example of W. H. Auden." Yale French Studies 89 (1996): 103-112. Print.

Mendelson, Edward. Ed. The Complete Works of W. H. Auden. Prose: 1939-1948. Vol. II. New Jersey: Princeton, 2002. Print.

Mendelson, Edward. Ed. The Complete Works of W. H. Auden. Prose: 1963-1968. Vol. V. New Jersey: Princeton University Press, 2015. Print.

Migne, Jacques Paul. Ed. "St. Augustine, En. in Ps. 103, 1,15: PL 37, 1348”. Patrologia Latina. Paris: 1841-1855.

Moss, Walter G. “W. H. Auden's Wisom, Faith, and Humor.” Wisdom Page. n.d. Web. 05 May 2019. $<$ https://www.wisdompage.com/WHAudensWisdomFaithandHumor.pdf $>$.

Mutter, Matthew. "'The Power to Enchant that Comes from Disillusion': W. H. Auden's Criticism of Magical Poetics." Journal of Modern Literature 34.1 (2010): 58-85. Print.

O’Brien, Sean. “Auden in Prose." Auden in Context. Ed. Tony Sharpe. Cambridge: Cambridge University Press, 2013. 329-336. Print.

Perry, Seamus. "Auden's Forms." Auden in Context. Ed. Tony Sharpe. Cambridge: Cambridge University Press, 2013. 369-380. Print.

Perry, Seamus. "Auden Unparadized", Chatterton Lecture on Poetry. Proceedings of the British Academy 162 (2008): 68-91. Print.

Pollnitz, Christopher. “Auden's Styles of Verse.” Sydney Studies in English 3 (1977): 74102. Print.

Reeves, Gareth. "Auden and Religion." The Cambridge Companion to W. H. Auden. Ed. Stan Smith. Cambridge: Cambridge University Press, 2005. 188-199. Print.

Sharpe, Tony. Ed. W. H. Auden in Context. Cambridge: Cambridge University Press, 2013. Print.

Shelley, Percy Bysshe. A Defense of Poetry. Ed. Albert S. Cook. Boston: Ginn and Company, 1891. Print.

Spears, Monroe K. The Poetry of W. H. Auden. New York: Oxford University Press, 1963. Print. 